\title{
Editorial
}

http://dx.doi.org/10.34181/rbg.2019.v2n1.p5-6.51

\section{Os saberes e fazeres, políticas públicas e transversalidade da gastronomia}

Knowledge and practices, public policies and transversality of gastronomy

Reafirmando o seu compromisso com o conhecimento científico, anunciamos o segundo volume da RBG - Revista Brasileira de Gastronomia, editada pelo Senac Santa Catarina que segue, assim, propiciando um espaço de divulgação de pesquisas e reflexões no campo da Alimentação e Gastronomia.

Do resgate de tradições gastronômicas, manutenção de saberes e fazeres, identidade cultural, representação da gastronomia no cinema e políticas públicas envolvendo sua rede produtiva - são alguns dos temas abordados pelos autores nesta edição e refletem um pouco da interdisciplinaridade e transversalidade da alimentação e da gastronomia.

O primeiro texto, "Moqueca capixaba: la receta de una identidad. Un estudio sobre la relación entre la comida y las representaciones de la identidad en la provincia de Espírito Santo, Brasil", de Manuela Ferreira Nunes Pereira Delisa e Patrícia Merlo, as autoras tratam das possíveis relações de identidade que um prato pode trazer àqueles que o executam e/ou consomem. $A$ análise parte de um prato tradicional da cultura capixaba: a moqueca capixaba.

Luanda Batista Demarchi dos Santos e Lucas Rodrigues da Silva em "Cores, gastronomia e cinema: um estudo sobre a representação da gastronomia no cinema", buscam explorar outras representações da gastronomia, através do cinema. Analisando a paleta cromática de seis filmes que abordam a temática gastronomia e/ou cozinha, lançados entre 1991 e 2010, trazem análises do uso das cores com a finalidade de detectar, conhecer e compreender mudanças culturais, tecnológicas e de percepção.

Fechando a edição, Ítalo de Paula Casemiro analisa os avanços, desdobramentos e desafios para a gastronomia do estado do Rio de Janeiro a partir da Lei no 7.180 de 2015. Seu artigo, "Marco referencial da gastronomia como cultura no estado do Rio de Janeiro: o mise-en-place para a gastronomia carioca está posto? Desdobramentos e perspectivas no âmbito da gastronomia e da cultura para o Rio de Janeiro", destaca os desdobramentos para a alimentação, cultura, turismo e pesquisa no estado.

A história contada na imagem que ilustra a capa deste número tem relação intrínseca com os saberes e fazeres e a valorização da identidade cultural de um local. É o registro de uma das etapas do processo de fabricação artesanal das panelas de barro no bairro de Goiabeiras Velha, Vitória/ES - a impermeabilização com tintura de tanino. A matéria prima continua sendo a argila, extraída da mesma procedência há anos e modelada manualmente - e sobretudo por figuras 
femininas - através de um conhecimento técnico e habilidade apreendidos e repassados através de gerações. A panela de barro é item comum no fazer e servir moqueca e, em 2000, o Ofício das Paneleiras de Goiabeiras recebeu o título de Patrimônio Cultural do Brasil, concedido pelo Instituto do Patrimônio Histórico e Artístico Nacional - IPHAN. A fotografia, de autoria de Vitor Jubini, está disponível como domínio público na conta do Flickr do Ministério do Turismo do governo brasileiro.

Desejamos uma boa leitura, agradecemos o comprometimento dos avaliadores e aos autores que escolheram a Revista Brasileira de Gastronomia para divulgar suas pesquisas. E seguimos desejando que este periódico contribua para a construção de um pensar científico e crítico em nossa sociedade.

Florianópolis, 01 de julho de 2019.

Nathália Bernardinetti Editora-Gerente Revista Brasileira de Gastronomia

\section{Referências}

IPHAN. Certidão. Publicado em 20 de dezembro de 2002. Disponível em: http://portal.iphan.gov.br/uploads/ckfinder/arquivos/Certidao_Goiabeiras.pdf. Acesso em 01 de julho de 2019. 